\title{
Nitrogen source apportionment modeling and the effect of land-use class related runoff contributions
}

\author{
G.A. Lindgren ${ }^{1}$, S. Wrede ${ }^{2,3}$, J. Seibert ${ }^{2 *}$ and M. Wallin ${ }^{1}$ \\ ${ }^{1}$ Department of Environmental Assessment, Swedish University of Agricultural Sciences, 75007 Uppsala, \\ Sweden \\ ${ }^{2}$ Department of Physical Geography and Quaternary Geology, Stockholm University, SE 10691 Stockholm, \\ Sweden. *Corresponding author. E-mail: jan.seibert@natgeo.su.se \\ ${ }^{3}$ Water Resources Section, Faculty of Civil Engineering and Geosciences, Delft University of Technology, 2600 \\ GA Delft, The Netherlands
}

Received 21 December 2006; accepted in revised form 22 August 2007

\begin{abstract}
Models simulating nutrient transport at the catchment scale are frequently used for source apportionment and thereby for finding cost-efficient management strategies for water quality improvements. One typical modelling approach at the catchment scale is the use of leaching coefficients (mass per unit flow of water) to compute the nutrient input based on land-use information. In this study two different such model approaches, the lumped Fyrismodel and the distributed HBV-N-D model, were compared based on simulations for the River Fyris catchment in central Sweden. A major difference between the models were different assumptions of specific runoff variations between different land-use classes. These differences had a considerable effect on the computed source apportionment. The higher specific runoff from agricultural areas in the HBV-N-D model compared to the Fyrismodel resulted in a larger contribution of agricultural areas to the total nitrogen export. These results demonstrate the importance of the assumptions of the spatial variation of specific runoff on source apportionment HBV-N-D model estimations.
\end{abstract}

Keywords Fyrismodel; HBV-N-D model; leaching coefficients; model comparison; River Fyris catchment; source apportionment

\section{Introduction}

Eutrophication of lakes and coastal marine environments as well as the resulting deterioration of ecosystems is a problem occurring in many places around the world (Nixon 1995; Smith et al. 1999) and is predicted to continue to increase (Tilman et al. 2002). In order to mitigate these problems there is a widely acknowledged need for the reduction of nutrient inputs to receiving water bodies (HELCOM 1993; Ministry of Sustainable Development Sweden 2005; Boesch et al. 2006). As a major contributor, riverine nutrient loads are one target for such reductions.

Cost-efficient reduction of riverine loads requires the identification of the nutrient sources in the catchment and their relative contribution to the total nutrient loads, i.e. the source apportionment. The relative contribution of different nutrient sources to the inputs into the catchment (gross load) is, in general, not equal to their relative contribution at the catchment outlet (net load), due to the nutrient retention in the different hydrological sub-systems, e.g. in the groundwater, stream and lake systems. This retention depends on the hydrological pathways from the sources to catchment outlet and these pathways are different for different sources. The source apportionment of nutrients, which includes quantification of nutrient inputs and the retention within the catchment, has received considerable attention in recent years and is commonly approached by catchment-scale nutrient transport modeling 
(e.g. Billen and Garnier 1999; Alexander et al. 2000; Arheimer and Brandt 2000; de Wit 2001; Neitsch et al. 2002; Wade et al. 2002).

Diffuse source nutrient inputs, in particular from agricultural areas, are in many cases the major contributor to the total inputs, and an accurate quantification is therefore needed to obtain a reliable source apportionment. One typical approach to quantify diffuse source inputs is the use of leaching coefficients (Johnsson and Hoffmann 1998; Arheimer and Brandt 2000; Brandt and Ejhed 2002; Johnsson and Mårtensson 2002; Kyllmar et al. 2005). These coefficients are multiplied by the runoff from a particular land-use area to compute the gross load resulting from this diffuse-source area. Since runoff is used to compute the loads, it is interesting to investigate how different representations of catchment runoff influence the source apportionment resulting from nutrient transport models, which use a leaching coefficient approach for nutrient input estimation.

In the present study we focus on total nitrogen $\left(\mathrm{N}_{\text {tot }}\right)$ transport in river systems. The objective was to calculate and compare the $\mathrm{N}_{\text {tot }}$ source apportionment in the River Fyris catchment in central Sweden using two different catchment-scale nutrient transport models, the Fyrismodel (Kvarnäs 1996; Sonesten et al. 2004; Hansson et al. 2006) and the HBV-N-D model (Wrede 2006). These models both use a leaching coefficient approach and the same coefficients as well as most other input data. The main difference between the two models, besides different geographical resolution, is the way runoff is computed for the different land-use areas in the catchment. In the Fyrismodel the specific runoff is spatially uniform among different land-use classes in sub-catchments, whereas in the HBV-N-D model the specific runoff varies among different land-use classes, depending on detailed water balance computations. In this paper in particular the effects of these different runoff representations on the source apportionment were investigated.

\section{Fyrismodel description}

The Fyrismodel is a dynamic catchment-scale nutrient transport model that calculates the contribution of nutrient inputs from different sub-catchments to the nutrient loads at the catchment outlet and the associated source distribution. The temporal resolution of the model is one month, corresponding to the commonly available temporal resolution of long term water quality data time series in Sweden.

The monthly nutrient mass input to sub-catchment $i$ is calculated as

$S_{i}^{\mathrm{in}}(t)=\sum_{j} q_{i}(t) A_{i j} c_{i j}(t)+\sum_{k} S_{i k}^{\text {point,in }}(t)+S_{i}^{\text {atmospheric,in }}(t)$

with $q_{i}$ (mm/month) being the specific runoff in catchment $i$ and $j$ denoting the different land-use classes of area $A_{i j}$ and associated land-use specific leaching coefficients $c_{i j}$ in catchment $i$. Furthermore, $S_{i k}^{\text {point,in }}(\mathrm{kg} /$ month) is the monthly nutrient input mass from point source $k$ in catchment $i$. Nutrient inputs from households that are not connected to municipal wastewater treatment plants are aggregated over each sub-catchment and included as separate $S_{i k}^{\text {point,in }}$ (kg/month) terms. $S_{i}^{\text {atmospheric,in }}(\mathrm{kg} / \mathrm{month})$ is atmospheric deposition onto water bodies in catchment $i$.

The nutrient inputs are subject to retention along the pathways from the sources to the catchment outlet. The pathways through the catchment are defined by the upstreamdownstream relations of the different sub-catchments. For every sub-catchment $i$ the contribution to the monthly nutrient load at the catchment outlet is calculated as

$S_{i}^{\text {out }}(t)=S_{i}^{\text {in }}(t) \prod_{m}\left(1-R_{m}(t)\right)$

with $m$ being the counter for the catchments along the pathway from sub-catchment $i$ to the catchment outlet. $R_{m}(-)$ is the retention factor, i.e. the fraction of nutrient inputs into 
sub-catchment $m$ that are retained within sub-catchment $m . R_{m}\left(R_{i}\right.$ when no particular pathway $m$ is considered) is quantified by

$R_{i}(t)=\left(k_{T}+T \frac{1-k_{T}}{20}\right) \frac{k_{d}}{q_{i}^{H L}+k_{d}}$

where $T$ is the water temperature in degree Celsius, $k_{T}(-)$ a calibration parameter that allows for tuning the degree of temperature dependence of the retention factor, and $k_{d}(\mathrm{~m} / \mathrm{s})$ a second calibration parameter that allows for tuning the discharge dependence of the retention factor. Furthermore, $q_{i}^{H L}=Q_{i} / A_{i}^{\text {water }}(\mathrm{m} / \mathrm{s})$ is the hydraulic load, i.e. the ratio of discharge $Q_{i}\left(\mathrm{~m}^{3} / \mathrm{s}\right)$ and water body area $A_{i}^{\text {water }}\left(\mathrm{m}^{2}\right)$ in sub-catchment $i . Q_{i}$ is calculated as the sum of upstream discharges, based on the area specific discharges and areas of upstream sub-catchments.

Equation (3) is derived from a mass balance equation assuming a 0-D continuously stirred tank reactor with a first-order decay reaction (e.g. Ahlgren et al. 1988) and an empirical temperature dependence of this process. This formulation thus represents seasonally variable retention that depends on water discharge, water temperature and water body area, and is linear in nutrient input loads.

The total monthly nutrient mass load at the catchment outlet is then calculated as the sum of the contributions of all inputs from all sub-catchments:

$S^{\text {out }}(t)=\sum_{i} S_{i}^{\text {out }}(t)$

The source distribution is obtained with Equations (1)-(4). However, the terms in Equation (1) are in this case not summed, but treated separately for each type of source area throughout the calculations.

\section{HBV-N-D model description}

The HBV-N-D model is a refined and distributed (grid-based) version of the conceptual nitrogen transport model HBV-N (Arheimer 1998) and allows daily simulations of nitrogen transport, retention and source apportionment at the catchment scale with a spatial resolution of $250 \times 250 \mathrm{~m}^{2}$. The HBV-N-D model uses a simple nitrogen transport model that is driven by runoff, which is simulated using daily precipitation, temperature and monthly evaporation as input.

The hydrologic part of the model is a distributed (grid-based) version of the HBV model (Bergström 1976, 1992). The model has a modular structure of sequentially linked routines and functions including a snow module that simulates snowmelt with the degree day method, a soil routine in which groundwater recharge and actual evaporation are functions of the actual water storage in a soil box, and a runoff generation routine in which runoff formation is represented by linear storage equations. Key elements for the spatial distribution of the hydrological model such as the implementation in the PCRaster (Karssenberg et al. 2001) modeling environment and the use of a single-flow-direction algorithm (O'Callaghan and Mark 1984) for lateral cell to cell routing, were adopted from the $\mathrm{TAC}^{\mathrm{D}}$ model (Uhlenbrook et al. 2004). Five different types of runoff generation conceptualizations were used, reflecting different hydrological processes: forests, agricultural areas, wetlands, urban areas and lakes. The different runoff formation and nitrogen transport processes were conceptualized using different linear-reservoir configurations and were parameterized individually. The different land-use types within a single grid cell were represented using fractions of total area per grid cell. A simple lake and stream routing module computes the downstream flow of discharge along the grid cells representing the stream network (Wrede 2006). 
The nutrient transport model is directly linked to the underlying distributed hydrological model using its water fluxes and storage levels to route nitrogen through the routines of the catchment model. The nutrient transport model is based on the conservative solute transport model concepts of the $\mathrm{TAC}^{\mathrm{D}}$ model (Wissmeier and Uhlenbrook 2007) using a parallel system of distributed storage analogous to the hydrologic model structure. It enables the simulation of advection and dispersion of nutrient concentrations, while depending solely on parameterization of the hydrologic model. The interconnection of water and nutrient fluxes is given by Equation (5):

$\frac{\mathrm{d} N}{N \cdot \mathrm{d} t}=\frac{\mathrm{d} V}{V \cdot \mathrm{d} t}$

where $V$ is the volume of water within the storage (expressed per unit area, mm), $N$ the amount of nutrients within the storage $(\mathrm{mg}$ ) and $t$ the time (d). Since Equation (5) only accounts for conservative solute transport the non-conservative transport is introduced by the lumped effect of $\mathrm{N}_{\text {tot }}$ retention that is expressed according to the concepts of the HBV-N model (e.g. Arheimer 1998). $\mathrm{N}_{\text {tot }}$ concentration dynamics are computed for each grid cell by the following equation:

$\frac{\mathrm{d}\left(c \cdot V_{a}\right)}{\mathrm{d} t}=c_{\mathrm{in}} \cdot Q_{\mathrm{in}}+S-\phi-c \cdot Q_{\mathrm{out}}$

where $c$ is the $\mathrm{N}_{\text {tot }}$ concentration $(\mathrm{mg} / \mathrm{mm}), V_{a}$ the water volume per unit area stored in the response box representing the freshwater body of groundwater, a river or a lake $(\mathrm{mm}), c_{i n}$ the inflow concentration $(\mathrm{mg} / \mathrm{mm}), Q_{i n}$ the specific runoff inflow $(\mathrm{mm} / \mathrm{d}), S$ the $\mathrm{N}_{\text {tot }}$ source input representing point sources, diffuse source emissions and/or atmospheric deposition depending on the storage type (e.g. groundwater, lake or stream) (mg/d), $Q_{\text {out }}$ the specific runoff outflow $(\mathrm{mm} / \mathrm{d})$ and $t$ the time $(\mathrm{d})$. In Equation $(6) \phi$ is a function representing the lumped effect of biochemical transformation $(\mathrm{mg} / \mathrm{d})$ and is varied for different freshwater bodies. It is based on empirical relationships between physical variables, landscape characteristics and concentration dynamics reflecting the net reduction by turnover processes. Turnover processes affect nitrogen loads while transported through different types of water bodies according to the following parameterizations, which were based on those used in the HBV-N model (Arheimer 1998): groundwater $\phi=k_{\text {Groundwater }} \cdot T_{20} \cdot c$, streams $\phi=k_{\text {River }} \cdot T_{20} \cdot c$ and lakes $\phi=k_{\text {Lake }} \cdot T_{20} \cdot c \cdot A_{\text {Lake }}$ where $k_{x}$ are calibration parameters $\left(\mathrm{mm}{ }^{\circ} \mathrm{C}^{-1} \mathrm{~d}^{-1}\right.$, for $k_{\text {Lake }}: \mathrm{mm}^{\circ} \mathrm{C}^{-1} \mathrm{~d}^{-1} \mathrm{~m}^{-2}$ ), $T_{20}$ is the mean air temperature during the preceding 20 days $\left({ }^{\circ} \mathrm{C}\right), c$ is the $\mathrm{N}_{\text {tot }}$ concentration $(\mathrm{mg} / \mathrm{mm})$ and $A_{\text {Lake }}$ is the lake area $\left(\mathrm{m}^{2}\right)$. The underlying assumption is that denitrification and plant uptake are major processes for nitrogen retention and that both processes depend on temperature (Windolf et al. 1996). At temperatures below zero biogeochemical processes are neglected and retention is assumed to be zero.

\section{River Fyris catchment characteristics}

The River Fyris catchment is located in central Sweden (Figure 1), has an area of $2005 \mathrm{~km}^{2}$ and a population of about 150,000, of which about 130,000 live in urban areas, mainly in Uppsala (SCB 2003). Long term average discharge into Lake Mälaren, which is Sweden's third largest lake, is about $13 \mathrm{~m}^{3} / \mathrm{s}(204 \mathrm{~mm} / \mathrm{yr})$. Land use consists of about $60 \%$ forest, $32 \%$ agriculture, $4 \%$ wetlands, $2 \%$ urban areas and $2 \%$ lakes. In the studied catchment the land-use distribution can be seen as a surrogate for the distribution of soil types; forests are typically associated with till and agricultural land with clay soils. Mean annual precipitation is $544 \mathrm{~mm} / \mathrm{yr}$ with $20-30 \%$ falling as snow, mean annual temperature is $5.2^{\circ} \mathrm{C}$ and the altitude ranges from $30-100 \mathrm{~m}$ a.s.1.. Stream chemistry data from eight stations and runoff data from two discharge measurement stations (Figure 1) were used for the model application. Climate 


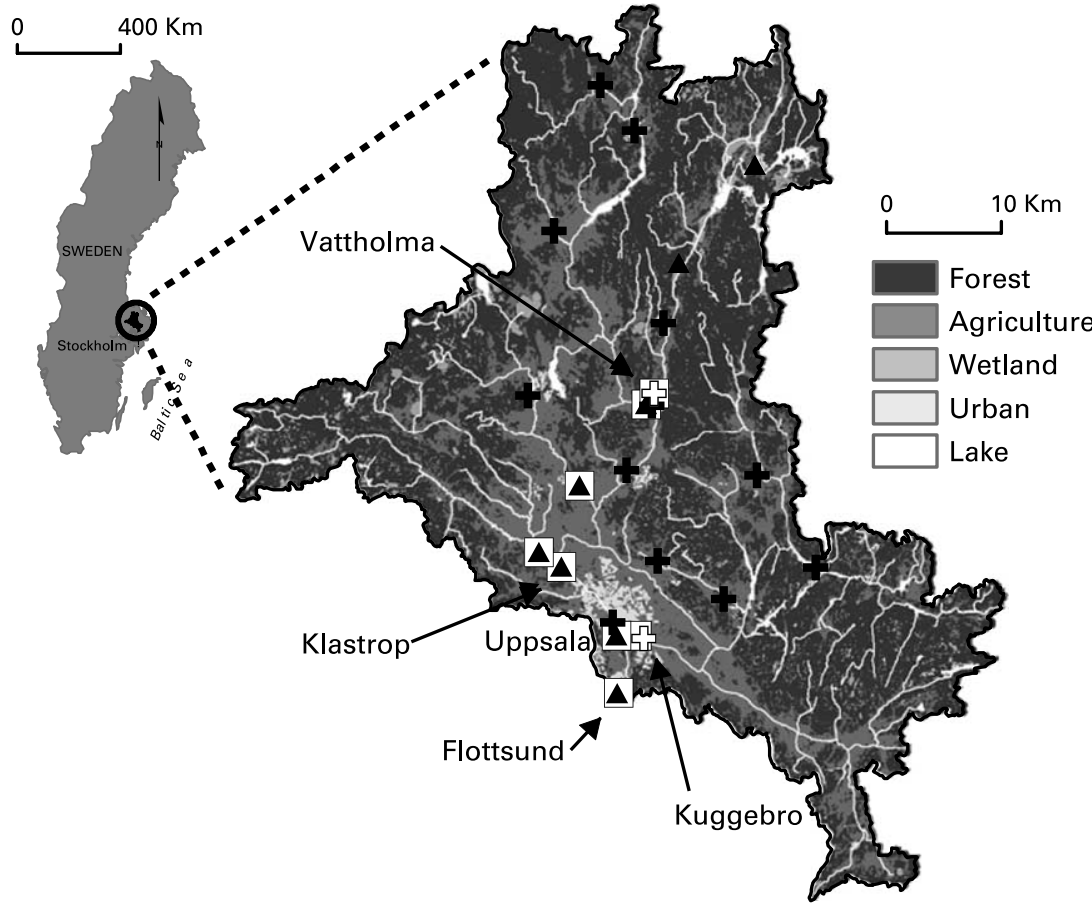

Figure 1 The River Fyris catchment and its location in Sweden, showing different land-uses, stream network (white lines), wastewater treatment plants (black crosses), stations for discharge measurements (white crosses), discharge modeling stations used in the Fyrismodel (black triangles), and tot- $\mathrm{N}$ observations (white squares)

data for the hydrological part of the HBV-N-D model was obtained from eight precipitation stations and three temperature stations and regionalized according to the inverse distance weighting method (for details see Wrede (2006)). For the Fyrismodel implementation the River Fyris catchment was divided into 67 sub-catchments as illustrated in Figure 2, which corresponds to the sub-catchment delineation defined in the pollution load compilation project PLC-4 (HELCOM 1999). The distribution of land-use areas in the River Fyris catchment was extracted from 1:100,000 and 1:250,000 geographical information system (GIS) maps. For agricultural areas, data from the 1999 block database of the Swedish board of agriculture that defines agricultural units was used together with data from the Integrated Administration and Control System (IACS) database of the Swedish board of agriculture that provides information on crop distribution.

\section{Nitrogen transport model input data}

For the different agricultural units specific total nitrogen leaching coefficients $c_{j}$ were available from results of the SOILNDB model (Johnsson and Hoffmann 1998; Johnsson and Mårtenson 2002). The computations of these coefficients are based on crop management, soil properties, climatic data and local hydrology. For the Fyrismodel the soil-type- and cropspecific leaching coefficients were aggregated in the sub-catchments as area weighted mean values, obtained from the block database. The resulting sub-catchment $\mathrm{N}_{\text {tot }}$ leaching coefficients ranged from $1.3 \mathrm{mg} / \mathrm{l}$ to $7.2 \mathrm{mg} / \mathrm{l}$ with a median of $3.5 \mathrm{mg} / \mathrm{l}$. For the HBV-N-D model mean leaching coefficients were also computed as area weighted mean for all agricultural areas within each grid cell. For both models a $\mathrm{N}_{\text {tot }}$ leaching coefficient of $0.6 \mathrm{mg} / \mathrm{l}$ was used for forested areas (Kyllmar 1995). For the Fyrismodel the clearcut area 
(a)

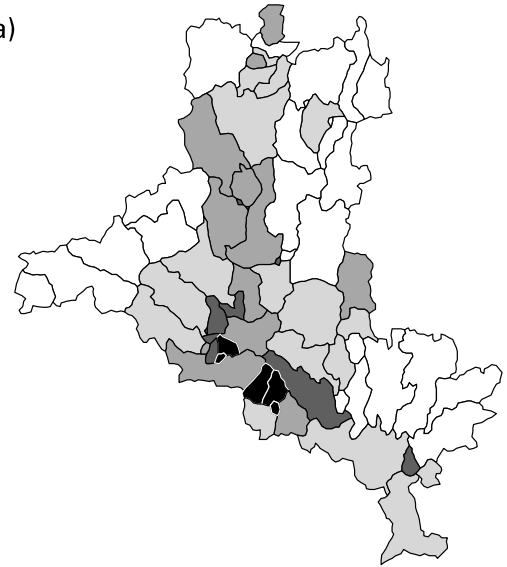

(c)

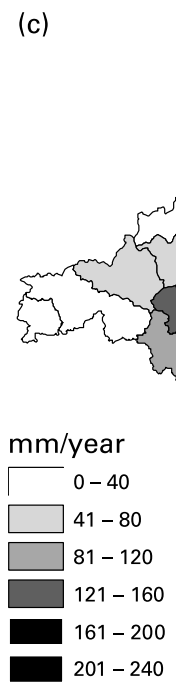

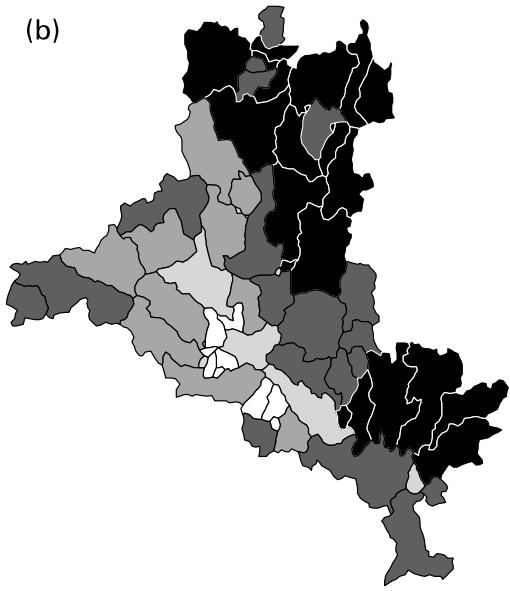

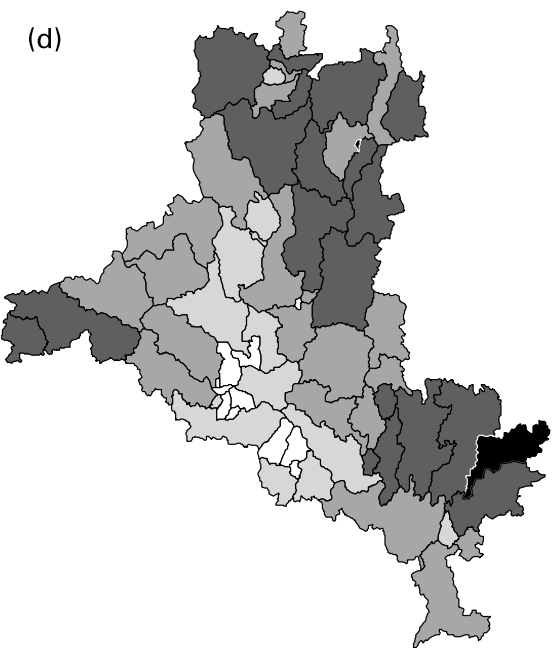

Figure 2 Runoff from agricultural and forest lands in the different sub-catchments of the River Fyris catchment normalized with respective sub-catchment area and averaged over the modeled period 1999-2004 in mm/yr. For the Fyrismodel implementation panel (a) shows runoff associated with agricultural areas and panel (b) runoff associated with forest areas. For results from runoff modeling with the HBV-N-D model panel (c) shows runoff associated with agricultural areas and panel $(\mathrm{d})$ runoff associated with forest areas

coefficient was $1.3 \mathrm{mg} / \mathrm{l}$ (Sonesten et al. 2004), for wetlands $1.2 \mathrm{mg} / \mathrm{l}$ (Sonesten et al. 2004) and for urban areas $1.2 \mathrm{mg} / \mathrm{l}$ (Bexelius 1999). The atmospheric nitrogen deposition on surface water bodies was $18 \mathrm{~kg} / \mathrm{month} / \mathrm{km}^{2}$ in the Fyrismodel and ranged from $10-18 \mathrm{~kg} /$ month $/ \mathrm{km}^{2}$ in the HBV-N-D model, based on yearly computations of the distributed MATCH (Mesoscale Atmospheric and Chemistry) model (Langener et al. 1995; atmospheric deposition on other land-use types is included in the land-use type specific leaching coefficients $c_{j}$ ). The differences in the parameterization of the atmospheric deposition onto surface waters in the two models is judged as negligible in the present context, as the contributions of this deposition are only about $1 \%$ in the Fyrismodel and $2 \%$ in the HBV-N-D model of the total nitrogen input into the catchment system.

Nitrogen input data for wastewater treatment plants were obtained with daily resolution for the largest wastewater treatment plant located in Uppsala and biweekly, monthly or annual resolution for other minor wastewater treatment plants. To account for the daily 
resolution of the HBV-N-D model the observed point source data were interpolated to a daily time step.

Nitrogen inputs from sewers not connected to municipal wastewater treatment were estimated based on data on the number of permanently inhabited households and secondary residence cottages with non-connected sewers and were considered per grid cell (HBV-N-D) or sub-catchment (Fyrismodel), respectively. The gross inputs from the households to their wastewater treatment facilities were set to $14 \mathrm{~g} / \mathrm{person} / \mathrm{d}$ for $\mathrm{N}$ (of which $1.5 \mathrm{~g} / \mathrm{person} / \mathrm{d}$ are blackwater inputs) (Swedish Environmental Protection Agency 2006). The type of wastewater treatment facility associated with a household was randomly distributed among the households, based on statistics on the distribution of treatment facilities (Ejhed et al. 2004). The treatment efficiency was based on a literature review of Palm et al. (2002), assuming a treatment efficiency of $10 \%$ in sludge separators, $45 \%$ in filter beds and $75 \%$ in infiltration facilities. Moreover, it was assumed that 2.5 people inhabit each household. To account for inhabitants spending time at other places a factor of 0.7 was applied to blackwater inputs. Secondary residence cottages were assumed to be used for 2 months per year on average. In the HBV-N-D model application these inputs were added in July and August. In the Fyrismodel time-variant inputs were not possible and the inputs from secondary residences were distributed evenly over the year.

The water temperatures at the water chemistry observation stations were shown to be very similar throughout the area and in the Fyrismodel application the temperature measured in the sub-catchment at Klastorp (Figure 1) was applied to all sub-catchments. In the Fyrismodel it is furthermore assumed that the turnover times in the lakes are not longer than the model time step of one month and that storage effects can be neglected. To account for the daily resolution of the HBV-N-D model and the delay between soil and water temperature to air temperature, a running mean of 20 day air temperatures is used to resemble the water temperature variations. Turnover times of lakes and streams are implicitly addressed by the HBV-N-D model concept by calibration of the nonlinear storage equations of the lake module and the calibration of the streamwater and nutrient distribution routine for the channel routing.

\section{Parameterization of discharge in the models}

For the Fyrismodel application the discharge is an input to the model and measured values were used in the two sub-catchments in which flow measurements were available (Figure 1). For seven sub-catchments indicated in Figure 1 the discharge was modeled with a parsimonious lumped model (Q model, Kvarnäs 2000). For all other sub-catchments of the Fyrismodel the specific runoff upstream of stations where discharge is measured or modeled was used in the calculations. It is important to note that in the Fyrismodel the runoff within any sub-catchment is assumed to be spatially uniform, i.e. differences in specific runoff for different land-use classes are neglected.

The rainfall-runoff model part of the HBV-N-D model is calibrated against daily runoff measurements at the discharge stations Vattholma and Sävja (close to Kuggebro; Figure 1) for the hydrological years 1994-1999 by employing the automated parameter estimator PEST (Parameter ESTimation) (Doherty 2005). PEST implements a Gauss-MarquardtLevenberg algorithm to combine the advantages of the inverse Hessian method and the steepest descent method to allow a faster and more efficient convergence towards the objective function minimum. The optimization of the hydrological module of the HBV-N-D model by PEST was based on the $R v$ criterion, which is a combination of the model efficiency and the volume error (Lindström et al. 1997), computed of the measured and simulated runoff time series. For the model comparison it is important to note that, in the HBV-N-D model, specific runoff is allowed to vary for different land-use classes. 
The runoff contribution from agricultural and forested areas differs considerably between the two models (Figure 2). Runoff contributions from agricultural areas are considerably smaller $(-32 \%)$ for the Fyrismodel than for the HBV-N-D model (Figure 2(a, c)). In contrast, the runoff associated with forest areas is considerably larger $(+26 \%)$ for the Fyrismodel than for the HBV-N-D model (Figure 2(b, d)). These differences are a direct consequence of considering land-use class related runoff contributions in the HBV-N-D model but uniform runoff contributions in the Fyrismodel. In the HBV-N-D model runoff from forested areas is smaller mainly due to smaller values for the snowfall-correction factor (SCF) for forested areas. Such smaller values of SCF are usually used for forested areas in HBV model applications. This is motivated by larger losses through snow interception in forested areas and has also been confirmed by a regionalization study (Seibert 1999). As the model is calibrated to match the total runoff volume the runoff from agricultural areas was larger for the HBV-N-D model. In total, the contribution to the discharge at the catchment outlet for the Fyrismodel is $2.98 \mathrm{~m}^{3} / \mathrm{s}$ from runoff generated in agricultural areas and $8.17 \mathrm{~m}^{3} / \mathrm{s}$ generated from forest areas. For the HBV-N-D model the corresponding values are $4.4 \mathrm{~m}^{3} / \mathrm{s}$ for agricultural areas and $6.47 \mathrm{~m}^{3} / \mathrm{s}$ for forest areas. Simulated discharge in general agreed well with observations with model efficiency values for the daily simulations of $0.8-0.9$ for the different gauged subcatchments. Time series of total runoff at the catchment outlet at Flottsund agreed well between the two models.

\section{Nutrient transport model calibration}

The Fyrismodel was calibrated manually by changing the parameters $k_{T}$ and $k_{d}$ to fit time series of observed $\mathrm{N}$ concentrations for the period 1999-2004 at the stations indicated in Figure 1. The coefficient of determination $\left(r^{2}\right)$ was used as the objective function.

Due to computational constraints the nutrient module of the HBV-N-D model was only calibrated for the hydrologic years 1999-2002 and to the same stations as the Fyrismodel by coupling the model to the automated parameter estimation program PEST. The calibration of the nutrient transport model included the parameters $k_{\text {Groundwater }}, k_{\text {Lake }}$ and $k_{\text {Wetland }}$. The best parameter set was selected within a specified range of parameter values by minimizing the sum of squared errors (i.e. differences between observed and simulated $\mathrm{N}_{\text {tot }}$ concentrations).

\section{Results}

The simulated time series of $\mathrm{N}_{\text {tot }}$ concentrations agreed visually in general with the pattern seen in the observations at different locations along the stream network (Figure 3 ) although the models were only partly able to explain the variance in the time series with $r^{2}$ values between 0 and 0.55 . We evaluated model performance also using scatter plots in which observed $\mathrm{N}_{\text {tot }}$ concentrations and loads at all stations and all time steps were compared to the respective simulated concentrations and loads (Figure 4). The loads were calculated by multiplying observed and modeled concentrations with discharge values. For $\mathrm{N}_{\text {tot }}$ concentrations and loads at all stations and all time steps the coefficient of determination $\left(r^{2}\right)$ was 0.29 and 0.91 , respectively, for the Fyrismodel and 0.35 and 0.91 , respectively, for the HBV-N-D model. For the loads at the catchment outlet and all time steps the model efficiency (Nash and Sutcliffe 1970) was 0.82 and $r^{2}$ was 0.97 for the Fyrismodel. The corresponding values were 0.79 and 0.89 for the HBV-N-D model. It should be noted that the models were calibrated to observed data at several stations along the stream network (and not only at the catchment outlet) to obtain a better simulation of the nitrogen variations within the catchment. The simulated time series for nitrogen concentrations show a more dynamic behavior for the HBV-N-D model than for the Fyrismodel (Figure 3). The reason is the monthly temporal resolution of the Fyrismodel which averages out the daily concentration changes as simulated by the HBV-N-D model. 


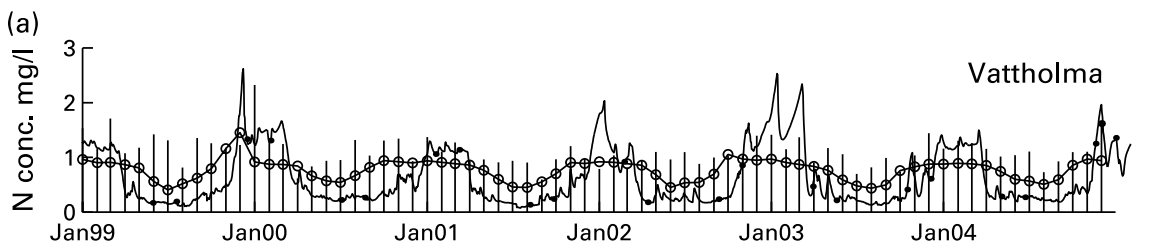

(b)

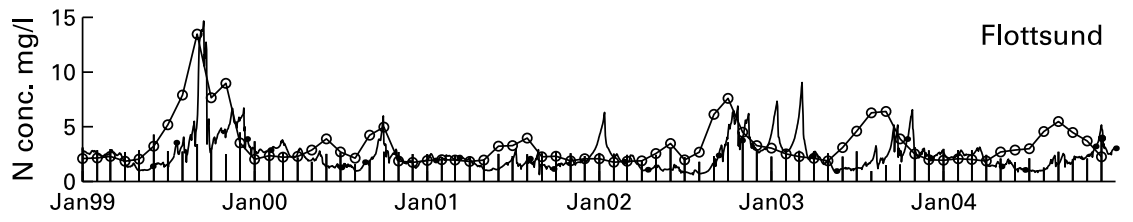

(c)

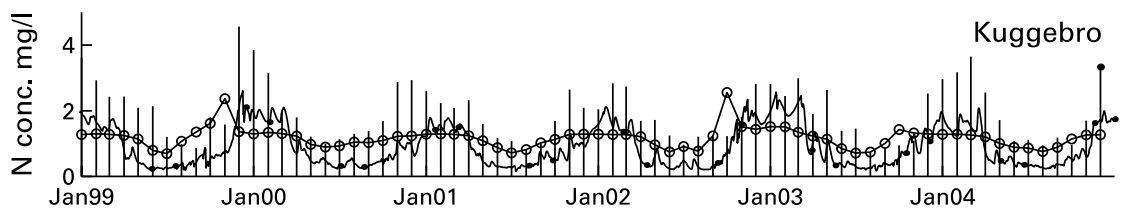

(d)

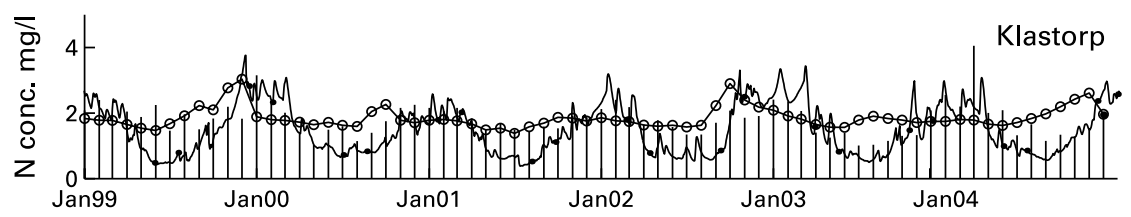

Figure 3 Time series of monthly values of total nitrogen concentrations: measured (stems), Fyrismodel (line with open circles) and HBV-N-D model (black line with dots) for the stations (a) Vattholma (mean of observed time series $=1.11 \mathrm{mg} / \mathrm{l}$; Fyrismodel: mean $=0.78 \mathrm{mg} / \mathrm{l}$ and $r^{2}=0.15 ; \mathrm{HBV}-\mathrm{N}-\mathrm{D}$ : mean $=0.67 \mathrm{mg} / \mathrm{l}$ and $r^{2}=0.22$ ), (b) Flottsund (mean of observed time series $=2.57 \mathrm{mg} / \mathrm{l}$; Fyrismodel: mean $=3.33 \mathrm{mg} / \mathrm{l}$ and $r^{2}=0.00$; HBV-N-D: mean $=2.51 \mathrm{mg} / \mathrm{l}$ and $r^{2}=0.01$ ), (c) Kuggebro (mean of observed time series $=1.94 \mathrm{mg} / \mathrm{l}$; Fyrismodel: mean $=1.18 \mathrm{mg} / \mathrm{l}$ and $r^{2}=0.12 ; \mathrm{HBV}-\mathrm{N}-\mathrm{D}$ : mean $=0.93 \mathrm{mg} / \mathrm{l}$ and $r^{2}=0.55$ ) and (d) Klastorp (mean of observed time series $=1.81 \mathrm{mg} / \mathrm{l}$; Fyrismodel: mean $=1.85 \mathrm{mg} / \mathrm{l}$ and $r^{2}=0.01$; HBV-N-D: mean $=1.53 \mathrm{mg} / \mathrm{l}$ and $r^{2}=0.43$; location of stations indicated in Figure 1)

For both models the total gross loads were largest for agriculture, followed by point source inputs and forest contributions. However, the contributions from different nitrogen source types to the $\mathrm{N}_{\text {tot }}$ inputs (gross loads) upstream from the measurement and calibration stations Vattholma, Klastorp, Kuggebro and Flottsund (Figure 1) varied between the two models (Figure 5).

For all stations, the higher agricultural gross loads of the HBV-N-D model outweighed the higher forest inputs of the Fyrismodel and thus the sum of nitrogen gross loads from all sources was larger for the HBV-N-D model than for the Fyrismodel (Figure 5). For instance, upstream of Flottsund (i.e. for the entire catchment), the total gross loads were about $13 \%$ lower for the Fyrismodel than for the HBV-N-D model, with agricultural gross loads being $28 \%$ lower and forest gross loads being about $25 \%$ higher for the Fyrismodel. All other sources were comparatively small, with differences in gross load values arising due to slightly different atmospheric deposition rates used in the two models, and the effects of aggregation or interpolation of underlying input data to the different spatial resolutions of the two models. Furthermore, comparison of the bars for the different stations in Figure 5 illustrate that forest areas are predominant in the upstream parts of the catchment and that the 

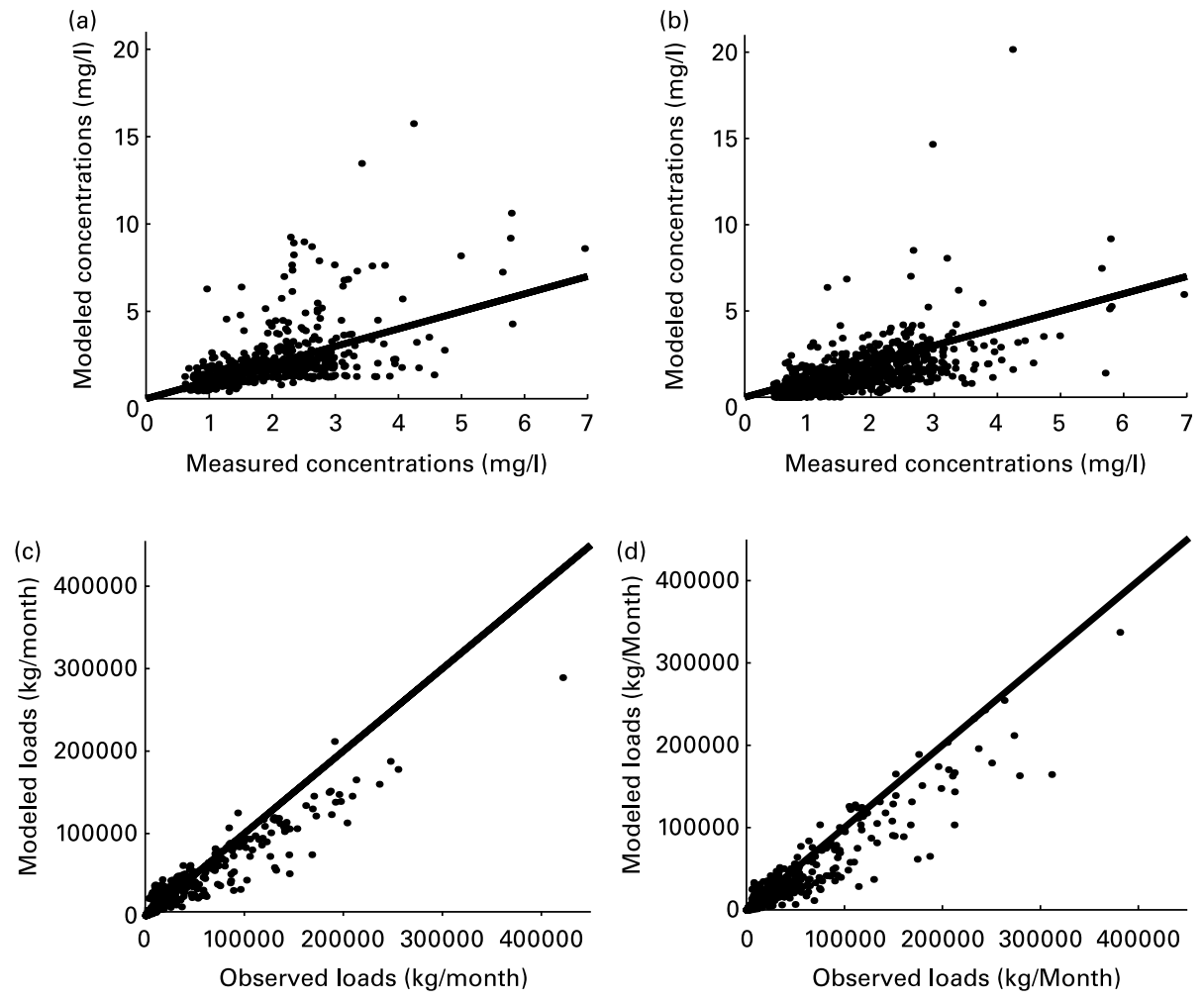

Figure 4 Comparison of measured and modeled nitrogen concentrations for all stations and time steps for which the models were calibrated resulting from (a) the best fit Fyrismodel calibration and (b) the best fit HBV-N-D model calibration. Modeled and observed nitrogen loads for all stations and time steps for which the models were calibrated are illustrated for (c) best fit Fyrismodel calibration and (d) best fit HBV-N-D model calibration. Observed loads were calculated by multiplying measured concentrations with modeled discharges or for the Fyrismodel and the two discharge observation stations with observed discharges. The lines show the 1:1 relation in all panels

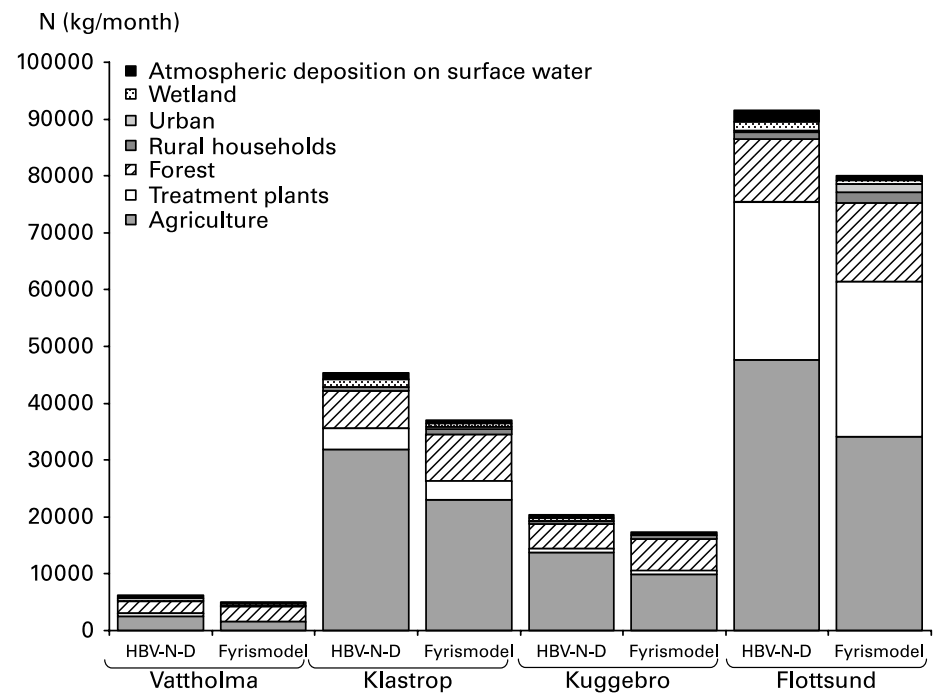

Figure 5 Modeled average monthly nitrogen contributions from different source types to the nitrogen inputs (gross loads) upstream of the measurement and calibration stations Vattholma, Klastorp, Kuggebro, and Flottsund (locations of stations indicated in Figure 1) 
major point source inputs are emitted close to the outlet, in particular from the Uppsala wastewater treatment plant.

Also the contribution of different nitrogen source types to the $\mathrm{N}_{\text {tot }}$ load at the different points along the stream network (net loads) differed considerably (Figure 6). The results presented in Figure 6 are commonly called the source apportionment. Comparing the different source contributions in Figures 5 and 6 indicates that the retention simulated by the Fyrismodel was smaller than that simulated by the HBV-N-D model. For instance, the total retention upstream of Flottsund was about $23 \%$ for the HBV-N-D model and about $8 \%$ for the Fyrismodel. The retention in the entire catchment resulting from the HBV-N-D model for agricultural inputs was about $21 \%$, for forest inputs about $39 \%$, and for point source inputs about $16 \%$. For the Fyrismodel the retention resulting for agricultural inputs was about $9 \%$, for forest inputs about $17 \%$ and for point source inputs only about $1.6 \%$.

\section{Discussion}

The $\mathrm{N}_{\text {tot }}$ simulations were of similar goodness as obtained in other nitrogen simulation studies, but obviously the fit was far from being perfect. Plotting simulated versus observed $\mathrm{N}_{\text {tot }}$ concentrations showed a considerable scatter. The scatter was much smaller for the respective loads (i.e. concentration multiplied by runoff). While the interest often is in nutrient loads rather than concentrations, the simulation of concentrations allows better evaluation of model performance with regard to nutrient simulations. Since loads are dominated by runoff rather than concentrations, using loads for evaluation is a test of the simulated runoff rather than the simulated nutrient dynamics. While there certainly is a need

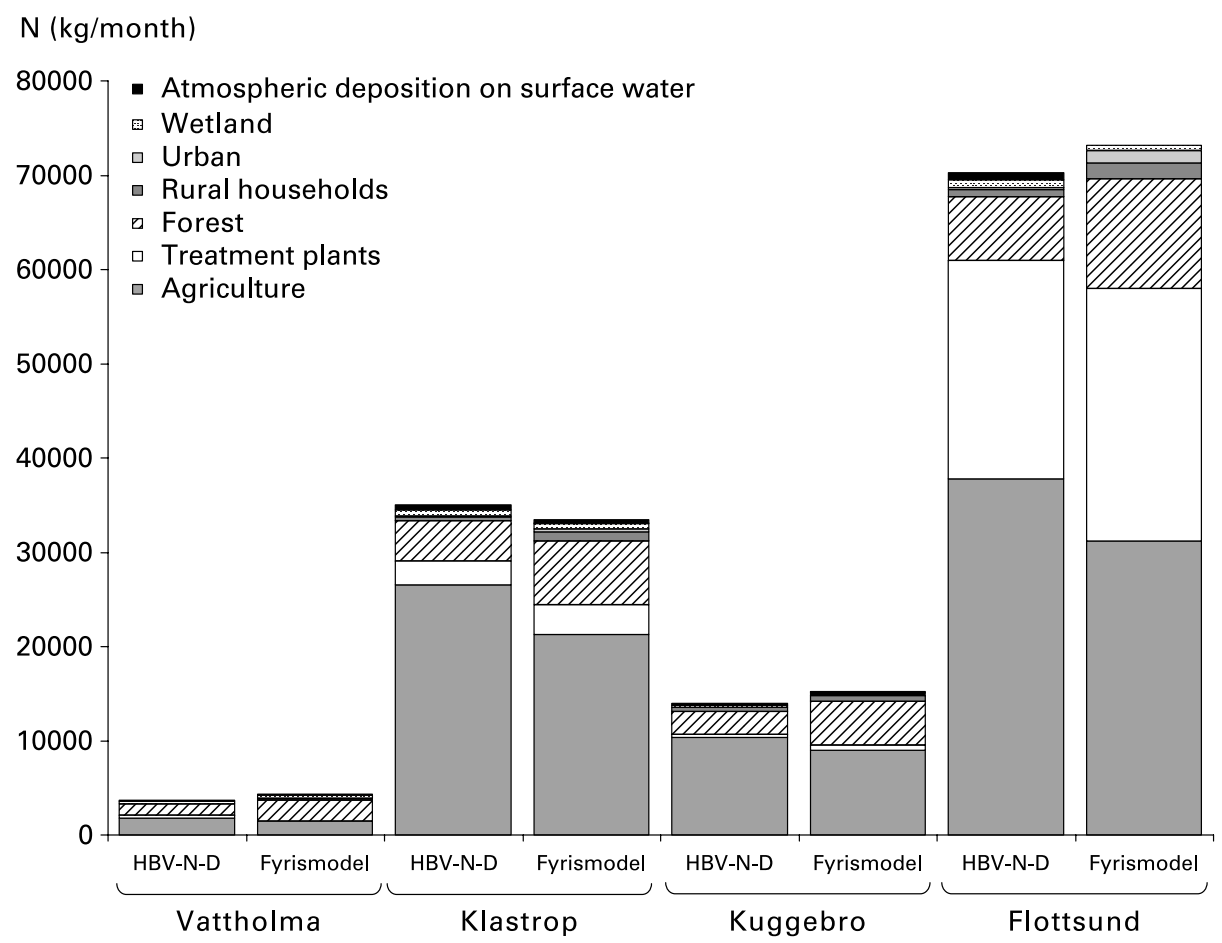

Figure 6 Modeled average monthly nitrogen contributions of different source types to the total nitrogen loads (net loads) at calibration stations Vattholma, Klastorp, Kuggebro and Flottsund for the Fyris and HVB-N-D models, respectively (locations of stations indicated in Figure 1) 
to improve the model performance of nitrogen simulation, the focus in this study was to evaluate the importance of the assumptions about runoff variations between different landuse classes.

The different assumptions about variations of specific runoff between agricultural and forested areas had an obvious effect on the nitrogen simulations. The agricultural nitrogen leaching coefficients were considerably larger (on average around $3.5 \mathrm{mg} / \mathrm{l}$ ) than the forest leaching coefficients $(0.6 \mathrm{mg} / \mathrm{l})$. Therefore, the larger runoff contributions from agricultural areas in the HBV-N-D model led to a higher total gross load, because the increase in load from the agricultural areas was larger than the corresponding decrease for forested areas. The about 26\% higher runoff contributions from the forest and about 32\% lower runoff contributions from agricultural areas for the Fyrismodel in comparison to the HBV-N-D model is therefore reflected in the about $25 \%$ higher forest and about $28 \%$ lower nitrogen gross load resulting for the Fyrismodel at the catchment outlet in Flottsund (Figure 5). In general, the potential increase or decrease of the total loads due to different distributions of runoff contributions from these areas increases with increasing difference between leaching coefficients for different areas. In other words, it becomes more important to accurately quantify the relative runoff contributions of different areas when the difference in leaching coefficients is larger between the areas.

The simulated retention in the Fyrismodel was smaller than in the HBV-N-D model. The reason is that, irrespective of gross load quantification (Figure 5), both models are calibrated to fit measured concentrations and loads at the measurement stations (Figures 1, 3 and 4), and thus the total retention becomes linked to the total gross inputs (Figure 6 bars for Flottsund). While the representation of the retention processes differs between the two models, the difference in retention is mainly an effect of the smaller gross loads in the Fyrismodel, which requires a smaller retention to match the observed levels on stream $\mathrm{N}_{\text {tot }}$ concentration. These results provide an example of the issue of uncertainties in the gross load and the consequences on simulated retention rates (Beven et al. 2005).

The difference in total retention in the catchment affects the various sources differently due to the spatial distribution of the sources, but also because retention in the models depends on the discharge which differs between the two models in areas dominated by either forest or agricultural areas. These differences in retention of the various source types cause that the relative contributions to the total net load (Figure 6) differ from the relative contributions to the total gross load (Figure 5). In other words, different representations of the runoff contributions from different areas not only change the gross load distribution but also the retention patterns in the catchment.

Due to the rather low retention of the major inputs from point sources (1.6\% and $16 \%$ for Fyrismodel and HBV-N-D model, respectively) and agricultural areas (9\% and $21 \%$ for Fyrismodel and HBV-N-D model, respectively) these differences might not have a huge impact on the cost efficiency of nitrogen source abatement measures based on the two model implementations. However, in some cases these differences may be of importance. For instance, the point source inputs that are mainly emitted close to the catchment outlet have about a tenfold larger retention according to the HBV-N-D model than according to the Fyrismodel.

While this model comparison study focused on the importance of runoff distribution for nitrogen simulations, there are obviously other issues which cause uncertainties in the model predictions. For instance, parameter uncertainty might be caused by the coupled simulation of both runoff and nitrogen because the additional information contained in the two datasets (runoff and nitrogen) might not compensate for the increased number of parameters. The temporal resolution of the models is another issue. The monthly time step of the Fyrismodel agrees with the typical resolution of stream chemistry measurements, but then of course the 
one (or two) grab samples in a certain month might not represent the monthly average, which is simulated by the model. The daily concentrations simulated using the HBV-N-D model agree better with the instantaneous stream chemistry data. On the other hand, for most time steps there was no observed data available for comparison, i.e. variations from day to day could neither be calibrated nor validated. These different assumptions that underly the calibration lead to parameter and model uncertainty that may influence resulting source distributions.

\section{Conclusions}

We calculated total-nitrogen source distributions in the Swedish River Fyris catchment with two different catchment-scale nutrient transport models, the Fyrismodel (Kvarnäs 1996; Sonesten et al. 2004) and the HBV-N-D model (Wrede 2006). The two models were rather similar, both using a leaching coefficient approach and simple retention equations. Nevertheless, we found considerable differences in the source apportionment provided by the simulations of the two models. The simplifying assumption in the Fyrismodel of uniformly distributed area-specific runoff in sub-catchments leads to a considerably different source distribution than the land-use-related runoff contribution representation of the HBVN-D model, which can be argued to be somewhat more process-based (Figure 6). The larger the difference in land-use type specific leaching coefficients the more important it becomes to accurately quantify the runoff contributions from different land-use types. The results illustrate that a good fit to measured data after calibration does not necessarily imply a correct source apportionment. The model comparison instead revealed model uncertainty with respect to the delivery and retention of total nitrogen. These issues warrant improving simulation of retention processes. This model comparison study has also demonstrated the need for thorough model evaluation, testing and comparison to identify needs for improved process understanding and their representation in catchment-scale nutrient transport models. For this purpose benchmark basins like the River Fyris catchment, where extensive efforts have been made for the compilation of all available data, are useful.

\section{Acknowledgements}

We thank Jacob Nisell for help with handling the databases and geographic information systems. Thanks are due to Uppsala municipality and the Uppsala County Administration Board for providing data on wastewater treatment plants and rural households. We also thank L. Wissmeier and S. Uhlenbrook for providing the source code of the $\mathrm{TAC}^{\mathrm{D}}$ model which helped in the development of the HBV-N-D model

\section{References}

Ahlgren, I., Frisk, T. and Kamp-Nielsen, L. (1988). Empirical and theoretical models of phosphorous loading, retention and concentration vs. lake trophic state. Hydrobiologia, 170, 285-303.

Alexander, R.B., Smith, R.A. and Schwarz, G.E. (2000). Effect of channel size on the delivery of nitrogen to the Gulf of Mexico. Nature, 403, 758-761.

Arheimer, B. (1998). Riverine Nitrogen: Analysis and Modelling under Nordic Conditions. Linköping Studies in Arts and Science, 185. Tema University, Linköping, 12.

Arheimer, B. and Brandt, M. (2000). Watershed modelling of nonpoint nitrogen losses from arable land to the Swedish coast in 1985 and 1994. Ecol. Engng., 14, 389-404.

Bergström, S. (1976). Development and Application of a Conceptual Runoff Model for Scandinavian Catchments. Report No. RHO 7. SMHI, Norrköping.

Bergström, S. (1992). The HBV Model - Its Structure and Applications. RH No. 4. SMHI Hydrology, Norrköping.

Beven, K., Heathwaite, L., Haygarth, P., Walling, D., Brazier, R. and Withers, P. (2005). On the concept of delivery of sediment and nutrients to stream channels. Hydrol. Process., 19, 551-556. 
Bexelius, A. (1999). Sammanställning på dagvattenledningsnätet samt teoretisk beräkning av föroreningstransporter från dagvatten i Uppsala (in Swedish). Uppsala kommun, tekniska kontoret, VA-avdelningen, Uppsala.

Billen, G. and Garnier, J. (1999). Nitrogen transfers through the Seine drainage network: a budget based on the application of the 'Riverstrahler' model. Hydrobiologia, 410, 139-150.

Boesch, D., Hecky, R., O’Melia, C., Schindler, D. and Seitzinger, S. (2006). Eutrophication of Swedish Seas. Rapport 5509. Naturvårdsverket, Stockholm.

Brandt, M. and Ejhed, H. (2002). TRK, Transport - Retention - Källfördelning, belastning på havet (in Swedish). Rapport 5247. Naturvårdsverket, Stockholm.

de Wit, M.J.M. (2001). Nutrient fluxes at the river basin scale I: the PolFlow model. Hydrol. Process., 15, $743-759$.

Doherty, J. (2005). PEST: Model-independent Parameter Estimation, User Manual, Watermark Numerical Computing, Brisbane.

Ejhed, H., Malander, M. and Staaf, H. (2004). Kunskapsläget om enskilda avlopp i Sveriges kommuner En enkätstudie (in Swedish with English summary). Rapport 5415. Naturvårdverket, Stockholm.

Hansson, K., Wallin, M. and Lindgren, G. (2006). The FYRIS Model Version 2.0 - A Tool for Catchment-scale Modeling of Source Apportioned Gross and Net Transport of Nitrogen and Phosphorus in Rivers. Technical Description. Report 2006:17. Department of Environmental Assessment, Swedish University of Agricultural Sciences, Uppsala.

HELCOM (1993). The Baltic Sea Joint Comprehensive Environmental Action Programme. Baltic Sea Environment Proceedings, No. 48, Helsinki Commission, Baltic Sea Environment Protection Commission, Helsinki, Finland.

HELCOM (1999). Guidelines for the Fourth Baltic Sea Pollution Load Compilation (PLC-4). Baltic Sea Environment Proceedings, No. 93, Baltic Sea Environment Protection Commission, Helsinki, Finland.

Johnsson, H. and Hoffmann, M. (1998). Nitrogen leaching from agricultural land in Sweden - Standard rates and gross loads in 1985 and 1994. Ambio, 27, 481-488.

Johnsson, H. and Mårtensson, K. (2002). Kväveläckage från svensk åkermark, beräkningar av normalutlakning för 1995 och 1999, underlagsrapport till TRK (in Swedish). Rapport 5248. Naturvårdsverket, Stockholm.

Karssenberg, D., Burrough, P.A., Sluiter, R. and de Jong, K. (2001). The PCRaster software and course materials for teaching numerical modelling in the environmental siences. Trans. GIS, 5(2), 99-110.

Kvarnäs, H. (1996). Modellering av näringsämnen i Fyrisåns avrinningsområde. Källfördelning och retention (in Swedish). Report. Fyrisåns vattenförbund, Uppsala.

Kvarnäs, H. (2000). The Q Model, A Simple Conceptual Model for Runoff Simulation in Catchment Areas, Rapport 2000:15, Department of Environmental Assessment, Swedish University of Agricultural Sciences, Uppsala.

Kyllmar, K. (1995). Växtnäringsförluster till vatten från ett jordbruksområde i södra Dalarna 1989-94 (in Swedish). Rapport 26. Seminarier och Examensarbete, Division of Water Quality Management, Swedish University of Agricultural Sciences, Uppsala.

Kyllmar, K., Martensson, K. and Johnsson, H. (2005). Model-based coefficient method for calculation of N leaching from agricultural fields applied to small catchments and the effects of leaching reducing measures. J. Hydrol., 304, 343-354.

Langner, J., Persson, C. and Robertson, L. (1995). Concentration and deposition of acidifying air pollutants over Sweden: Estimates for 1991 based on the match model and observations. Water Air Soil Pollut., 85(4), 2021-2026.

Lindström, G., Johansson, B., Persson, M., Gardelin, M. and Bergström, S. (1997). Development and test of the distributed HBV-96 hydrological model. J. Hydrol., 201(1-4), 272-288.

Ministry of Sustainable Development Sweden (2005). Summary of Government Bill 2004/05:150, Environmental Quality Objectives: - A Shared Responsibility. Article No. M2006.26. Stockholm.

Nash, J.E. and Sutcliffe, J.V. (1970). River flow forecasting through conceptual models, 1. A discussion of principles. J. Hydrol., 10, 282-290.

Neitsch, S.L., Arnold, J.G., Kiniry, J.R., Williams, J.R. and King, K.W. (2002). Soil and Water Assessment Tool Theoretical Documentation, GSWRL Report 02-01, Grassland, Soil \& Water Research Laboratory, Temple, TX.

Nixon, S.W. (1995). Coastal marine eutrophication - A definition, social causes, and future concerns. Ophelia, 41, 199-219. 
O'Callaghan, J.F. and Mark, D.M. (1984). The extraction of drainage networks from digital elevation data. Comput. Vis. Graph. Image Process., 28, 328-344.

Palm, O., Malmén, L. and Jönsson, H. (2002). Robusta, uthålliga, små avloppssystem, en kunskapssammanställning (in Swedish). Rapport 5224. Naturvårdsverket, Stockholm.

SCB (2003). Statistik för avrinningsområden 2000 (in Swedish). Statistiska meddelanden serie MI 11 SM 0301. Statistiska Centralbyrån, Stockholm.

Seibert, J. (1999). Regionalisation of parameters for a conceptual rainfall-runoff model. Agric. Forest Meteorol., 98-99, 279-293.

Smith, V.H., Tilman, G.D. and Nekola, J.C. (1999). Eutrophication: impacts of excess nutrient inputs on freshwater, marine, and terrestrial ecosystems. Environ. Pollut., 100, 179-196.

Sonesten, L., Wallin, M. and Kvarnäs, H. (2004). Kväve och fosfor till Vänern och Västerhavet. Transporter, retention och åtgärdsscenariern inom Göta älvs avrinningsområde (in Swedish). Rapport No. 2004:33. Länsstyrelsen i Västra Götalands län, Göteborg.

Swedish Environmental Protection Agency (2006). Naturvårdsverkets allmänna råd till 2 och 26 kap. miljöbalken och 12-14 och 19 §§ förordningen (1998:899) om miljöfarlig verksamhet och hälsoskydd om små avloppsanordningar for hushållsspillvatten (in Swedish). NFS 2006:7. Naturvårdsverket, Stockholm.

Tilman, D., Cassman, K.G., Matson, P.A., Naylor, R. and Polasky, S. (2002). Agricultural sustainability and intensive production practices. Nature, 418, 671-677.

Uhlenbrook, S., Roser, S. and Tilch, N. (2004). Hydrological process representation at the meso-scale: the potential of a distributed, conceptual catchment model. J. Hydrol., 291(3-4), 278-296.

Wade, A.J., Durand, P., Beaujouan, V., Wessel, W.W., Raat, K.J., Whitehead, P.G., Butterfield, D., Rankinen, K. and Lepisto, K. (2002). A nitrogen model for European catchments: INCA, new model structure and equations. Hydrol. Earth Syst. Sci., 6, 559-582.

Windolf, J., Jeppesen, E., Jensen, J.P. and Kristensen, P. (1996). Modelling of seasonal variation in nitrogen retention and in-lake concentration: a four-year mass balance study in 16 shallow Danish lakes. Biogeochemistry, 33, 25-44.

Wissmeier, L. and Uhlenbrook, S. (2007). Distributed, high-resolution modelling of ${ }^{18} \mathrm{O}$ signals in a meso-scale catchment. J. Hydrol., 332(3-4), 497-510.

Wrede, S. (2006). Distributed Solute Transport Modelling in the Fyrisån Catchment in Sweden. MSc Thesis, Institute of Hydrology, University of Freiburg, Freiburg. 